\title{
99mTc labeled genistein kits: development methods and quality control for breast cancer radiotracer applications
}

\section{Danni Ramdhani ( $\nabla$ d.ramdhani@unpad.ac.id)}

Padjadjaran University

\section{Maula Eka Sriyani}

National Nuclear Energy Agency of Indonesia (BATAN)

Eva Maria W

National Nuclear Energy Agency of Indonesia (BATAN)

Nita Listiani

Padjadjaran University

Resmi Mustarichie

Padjadjaran University

Hiroshi Watabe

Tohoku University

\section{Research Article}

Keywords: Technetium-99m, genistein, kit, breast cancer, estrogen receptors $\beta$

Posted Date: November 4th, 2021

DOI: https://doi.org/10.21203/rs.3.rs-1009713/v1

License: (c) (i) This work is licensed under a Creative Commons Attribution 4.0 International License.

Read Full License 


\section{Abstract \\ Objective.}

Selective estrogen receptor modulators (SERMs) have been widely used to treat breast cancer, osteoporosis, and postmenopausal symptoms. SERMs have an affinity for estrogen receptors (ER) in target tissues and resist stimulation of the breast, bone, and endometrium. Genistein as an isoflavone compound that has a high affinity for ER $\beta$ targets makes it a potential target or prognostic marker for breast cancer. This study was carried out to develop ${ }^{99 \mathrm{~m}} \mathrm{Tc}$-genistein kit that can be used to detect breast cancer.

\section{Methods.}

The synthesis process and quality control were investigated to obtain the optimal formula for the ratio of a substance, reducing agent, optimal conditions of the synthesis reaction, physicochemical properties of the kit, and its stability to meet the requirements of radiochemical purity.

\section{Results.}

The radiochemical purity in the development of the radiopharmaceutical kit was $93.25 \% \pm 0.30 \%$. The physicochemical properties of the kit preparations showed hydrophilic properties, good plasma protein binding, no electrical charge, and were stable at storage temperatures.

\section{Conclusions.}

The radiochemical purity of the radiopharmaceutical kits meets the requirements of the United State Pharmacopeia and has good physicochemical properties to be developed into kits.

\section{Introduction}

The death rate caused by breast cancer globally in 2020 is 684,996 and this is predicted to increase every year ${ }^{1}$. Early detection of breast cancer, when it is small and has not spread, will be easier to treat successfully ${ }^{2}$. In addition, the sensitive method of detecting micrometastatic conditions allows therapy to be scaled up in a higher risk subset of patients, and avoids patients from potential unnecessary side effects of treatment ${ }^{3}$.

Selection of alternative treatments and predictive factors for breast cancer prognosis that are currently widely used include estrogen receptor-positive (ER+), carcinoembryonic antigen (CEA), progesterone receptor (PR), human epidermal growth factor receptor 2 (HER2), urokinase plasminogen activator (UPA), plasminogen activator inhibitor 1 (PAl-1). The evaluation of clinical variables, such as nodal involvement, 
tumor size, histological type, tumor grade, and surgical margins ${ }^{[4-6]}$. The active ER signal stimulates cell proliferation, and accounts for $75 \%$ of all diagnosed breast cancers ${ }^{7}$.

Genistein is an isoflavones compound that is abundantly found in soybean seeds with the chemical name [5,7-dihyroxy-3-(-4-hydroxyphenyl)-4H-1-benzopyran-4-one], shown to be potentially specific in the treatment of certain types of breast tumors ${ }^{8}$. Genistein shows a strong affinity for human estrogen receptor beta 9 .

The development of new radiopharmaceutical imaging kits is important for the early diagnosis of breast cancer and patient survival. Currently, more than $80 \%$ of nuclear medicine uses single-photon emission computerized tomography (SPECT) to detect cancer with radiopharmaceuticals ${ }^{10}$. Technetium- $99 \mathrm{~m}$ is the most preferred gamma-emitting radioisotope in the preparation of SPECT radiopharmaceuticals because it has ideal properties such as $6.02 \mathrm{~h}$ physical half-life, low cost, and $\mathrm{y}$-radiation energy $(0.1405 \mathrm{meV})$, and ready availability ${ }^{11-13}$.

This study aims to develop a ${ }^{99 m}$ Tc-genistein kit for the early detection of breast cancer patients specifically and accurately. In addition, we offer a less laborious method with direct labeling, of simple components with qualified radiochemical purity.

\section{Materials And Methods}

\section{Materials}

Genistein and $\mathrm{SnCl}_{2} \cdot 2 \mathrm{H}_{2} \mathrm{O}$ were purchased from Sigma-Aldrich, and the solvents used were purchased from Merck.

Instant thin layer chromatography-silica gel (ITLC-SG) (Agilent, Technologies), dose calibrator (Victoreen), Single Channel Analyzer (ORTEC). The Technetium-99m radioisotope was obtained from the Enviro Technetium-99m Generator, manufactured by Enviro Korea Co., Ltd.

\section{Methods}

Method for preparation of ${ }^{99 m} \mathrm{Tc}$ genistein kit. The preparation of ${ }^{99 \mathrm{~m}} \mathrm{Tc}$ genistein compound was carried out by optimizing the formulation of all parameters: genistein solution as ligand, $\mathrm{SnCl} \mathrm{Cl}_{2} \cdot \mathrm{H}_{2} \mathrm{O}$ solution as reducing agent, $\mathrm{pH}$ value, and incubation time. In addition, sodium pertechnetate solution [ $\left.{ }^{99 \mathrm{~m}} \mathrm{Tc}\right]$ with an activity 7.4 - $17 \mathrm{MBq}$ was added in the process of forming ${ }^{99 \mathrm{~m}} \mathrm{Tc}$ genistein. The radiochemical purity (RCP) of the complex formation is monitored by TLC and must fulfill the USP requirement of $>90 \%{ }^{14-15}$.

Thin-layer chromatography (TLC) procedure. Determination of the radiochemical purity of ${ }^{99 \mathrm{~m}} \mathrm{Tc}$ genistein from impurities ${ }^{99 \mathrm{~m}} \mathrm{TcO}_{2}$ and ${ }^{99} \mathrm{mcO}_{4}$ - using the TLC method. This quality control method is simple and practical to use. The stationary phase used is TLC SGF 254 with a mobile phase of $\mathrm{NaCl}$ 
solution. This TLC system aims to separate $\mathrm{TcO}^{4-}$ impurities, where $\mathrm{TcO}^{4-}$ will migrate and ${ }^{99 \mathrm{~m}} \mathrm{Tc}$ genistein compound will remain at the starting point.

The separation of ${ }^{99 \mathrm{~m}} \mathrm{TcO}_{2}$ was carried out with the stationary phase ITLC-SG and the mobile phase a mixture of $\mathrm{C}_{2} \mathrm{H}_{5} \mathrm{OH}: \mathrm{H}_{2} \mathrm{O}: \mathrm{NH}_{4} \mathrm{OH}(2: 5: 1)$. As a result, the impurity of ${ }^{99 \mathrm{~m}} \mathrm{TcO} 2$ will migrate carried away by the mobile phase onto the TLC plate, and the ${ }^{99 \mathrm{~m}} \mathrm{Tc}$ genistein compound will remain at the starting point. The strips were measured for their radioactive activity using SCA (Single Channel Analyzer), and the calculation of RCP of ${ }^{99 \mathrm{~m}} \mathrm{Tc}$ genistein is based on the equation:

$\%{ }^{99 m}$ Tc-Genistein $=100 \%-\left(\%{ }^{99 m} \mathrm{TcO}_{2}+\%{ }^{99} \mathrm{mcO}_{4}{ }^{-}\right)^{16}$

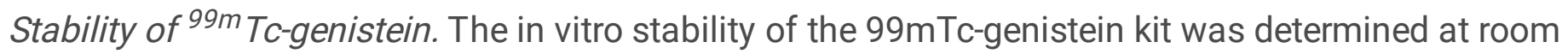
temperature. Measurements will be observed the percentage of radiochemical purity by TLC every 1 hour for 5 hours of observation time and its physical appearance.

Electric charge measurement. Determination of the charge of the ${ }^{99 \mathrm{~m}} \mathrm{Tc}$ genistein kit was carried out by electrophoresis method using Whatman no.1 paper (GE Healthcare). Whatman paper $(37 \mathrm{~cm} \times 1 \mathrm{~cm})$ is marked every $1 \mathrm{~cm}$ apart, with 0 in the middle. On the right, the scale of 18 is written for positive values, and the anode is placed, while the scale is 18 on the left for negative values and the cathode is placed. At the zero point, the ${ }^{99 \mathrm{~m}} \mathrm{Tc}$ genistein kit is spotted and the paper was immersed in $0.02 \mathrm{~N}$ phosphate buffer solution, pH 7.5. The electrophoresis device was supplied with a voltage of 350 Volts, 11-16 mA. After 1 hour, Whatman paper pieces were measured by SCA.

Determination of Lipophilicity. The test was conducted by adding $2 \mathrm{~mL}$ of 1 -octanol solution and $2 \mathrm{~mL}$ of $0.9 \% \mathrm{NaCl}$ (saline solution) $\mathrm{pH} 7.4$ into centrifuge tubes and adding $10-50 \mu \mathrm{L}$ of ${ }^{99 \mathrm{~m}} \mathrm{Tc}$-genistein solution. The solution was homogenized by vortexing for 1 minute and centrifuged at $3000 \mathrm{rpm}$ for 10 minutes. Each $100 \mu \mathrm{L}$ of the 1 -octanol fraction and saline solution was counted for radioactivity by SCA. The partition coefficient was determined by calculating the radioactivity ratio of 1-octanol and saline solution.

Measurement of plasma protein binding. Determination of plasma protein binding was carried out by precipitation method using TCA solution. A total of $500 \mu \mathrm{L}$ of blood samples were added to $50 \mu \mathrm{L}$ of radiopharmaceutical ${ }^{99 \mathrm{~m}} \mathrm{Tc}$ genistein and homogenized by vortex for 1 minute. The mixture was incubated for 10 minutes at $37^{\circ} \mathrm{C}$, then $1 \mathrm{~mL}$ of $0.9 \% \mathrm{NaCl}$ solution and $1 \mathrm{~mL}$ of $5 \%$ TCA solution were added. This solution was centrifuged at $3000 \mathrm{rpm}$ for 15 minutes. The precipitate formed is then separated from the supernatant. The supernatant solution was added again with $1 \mathrm{~mL}$ of TCA solution, the process of precipitation and separation was repeated. The precipitate fraction was washed again with the addition of $1 \mathrm{~mL}$ of $0.9 \% \mathrm{NaCl}$ solution, centrifuged and separated again. Radioactivity of the precipitate fraction (a) and the supernatant (b) will be measured by SCA and the plasma protein binding value is calculated by the following equation. 
plasma protein binding $(\%)=\frac{a}{(a+b)} \times 100 \%$

\section{Results And Discussion}

The process of labeling genistein with ${ }^{99 \mathrm{~m}} \mathrm{Tc}$ was carried out by extracting ${ }^{99 \mathrm{~m}} \mathrm{Tc}$ from a standard generator with a solution of $0.9 \% \mathrm{NaCl}$ solution. The chemical form of ${ }^{99 \mathrm{~m}} \mathrm{Tc}$ in the generator is $\mathrm{Na}^{99 \mathrm{~m}} \mathrm{TcO}_{4}$, which has a valence value of $7^{+}$. At this valence, technetium cannot bind to genistein, so a reducing agent is needed. There are many studies in the synthesis of ${ }^{99 \mathrm{~m}} \mathrm{Tc}$ radiopharmaceuticals using stannous chloride as a reducing agent, because it has good reducing power and is non-toxic. In addition, stannous chloride effectively facilitates the reaction during the radiolabeling process ${ }^{17-18}$. The reaction of decreasing the valence number of ${ }^{99 \mathrm{~m}} \mathrm{Tc}$ with the reducing agent $\mathrm{SnCl}_{2}$ can be explained by the following reaction ${ }^{19}$. The decrease in the valence of ${ }^{99 \mathrm{~m}} \mathrm{Tc}$ becomes more reactive so that it can form a ${ }^{99 \mathrm{~m}} \mathrm{Tc}$ genistein complex.

\section{$3 \mathrm{Sn}^{2+} \leftrightarrows 3 \mathrm{Sn}^{4+}+6 \mathrm{e}^{-}$ \\ $\underline{2^{99 m} \mathrm{TcO}_{4}^{-}+16 \mathrm{H}^{+}+6 \mathrm{e}^{-} \leftrightarrows 2^{99 \mathrm{~m}} \mathrm{Tc}^{4+}+8 \mathrm{H}_{2} \mathrm{O} \quad+}$ \\ $2{ }^{99 \mathrm{~m}} \mathrm{TcO}_{4}{ }^{-}+16 \mathrm{H}^{+}+3 \mathrm{Sn}^{2+} \leftrightarrows 2^{99 m} \mathrm{Tc}^{4+}+3 \mathrm{Sn}^{4+}+8 \mathrm{H}_{2} \mathrm{O}$}

The preparation process of ${ }^{99 \mathrm{~m}} \mathrm{Tc}$ genistein contained impurities $\mathrm{TcO}^{4-}$ and $\mathrm{TcO}_{2}$, which could be identified by a simple TLC method. The TLC method was carried out with 2 plates and 2 different mobile phases, aiming to overcome radiochemical purity calculations errors due to the presence of $\mathrm{TcO}_{2}$ and $\mathrm{TcO}_{4}{ }^{-}$impurities. The scheme for synthesizing of ${ }^{99 \mathrm{~m}} \mathrm{Tc}$ genistein compounds using the direct labeling method can be seen in Figure 1.

The optimum conditions for the labeling process of ${ }^{99 \mathrm{~m}} \mathrm{Tc}$ genistein with a concentration of $\mathrm{SnCl}_{2} \cdot 2 \mathrm{H}_{2} \mathrm{O}$ solutions were $15 \mathrm{mg} / \mathrm{mL}$, genistein concentration $10 \mathrm{mg} / \mathrm{mL}$, optimum pH at 8 , and incubation time of 10 minutes and obtained RCP of $93.25 \% \pm 0.30 \%$. These results indicate that the radiopharmaceutical formulation has met the requirements of the RCP, with a clear, colorless solution. Furthermore, this RCP value is predicted to be able to reach the target organ well so that it can emit photons to be detected on a gamma camera.

The stability test at room temperature. This test will obtain information on physicochemical changes and the RCP value of the preparation. The assay is carried out for 5 hours after incubation time, it is based on the half-life of ${ }^{99 \mathrm{~m}} \mathrm{Tc} 6.01$ hours. Therefore, the RCP value was calculated every 1 hour, for 5 hours of observation time. The stability results showed that the ${ }^{99 \mathrm{~m}} \mathrm{Tc}$ genistein preparation met the requirements as a radiopharmaceutical kit with an RCP $>90 \%$ for 2 hours and a clear physical appearance until the 5th hour (Table 1 and figure 2). 
Table 1

The stability test of ${ }^{99 m}$ Tc genistein at room temperature.

\begin{tabular}{|c|c|c|c|c|}
\hline \multirow{2}{*}{$\begin{array}{l}\text { Time } \\
\text { (min) }\end{array}$} & \multicolumn{2}{|c|}{ Impurities (\%) } & \multirow{2}{*}{$\begin{array}{l}\text { RCP (\%) } \\
\text { 99mTc genistein }\end{array}$} & \multirow[t]{2}{*}{ Appearance } \\
\hline & ${ }^{99} \mathrm{~m}^{-} \mathrm{T}_{2}$ & ${ }^{99} \mathrm{~m}^{-} \mathrm{TcO}_{4}$ & & \\
\hline 10 & $1.33 \pm 0.3$ & $5.66 \pm 0.4$ & 93.01 & clear, colorless \\
\hline 60 & $1.70 \pm 0.5$ & $6.28 \pm 0.12$ & 92.02 & clear, colorless \\
\hline 120 & $2.55 \pm 0.42$ & $6.90 \pm 0.16$ & 90.55 & clear, colorless \\
\hline 180 & $4.51 \pm 1.96$ & $8.67 \pm 1.84$ & 86.82 & clear, colorless \\
\hline 240 & $8.76 \pm 2.37$ & $10.48 \pm 2.58$ & 80.76 & clear, colorless \\
\hline 300 & $7.05 \pm 2.94$ & $17.98 \pm 2.08$ & 74.97 & clear, colorless \\
\hline
\end{tabular}

The room temperature stability of the ${ }^{99 \mathrm{~m}} \mathrm{Tc}$ genistein kit showed RCP values $>90 \%$ up to 2 hours. However, after 2 hours of storage at room temperature, the RCP value of the kit decreased due to the increase in impurity values of $\mathrm{TcO}_{4}{ }^{-}$and $\mathrm{TcO}_{2}$. This could be due to the reduced ${ }^{99 \mathrm{~m}} \mathrm{Tc}$, which has not been bound to genistein, can return to its original form because the reaction is irreversible ${ }^{20}$. The stability results also showed that the ${ }^{99 \mathrm{~m}} \mathrm{Tc}$ genistein kit had the appearance of a clear, colorless, and particle-free solution for up to 5 hours of observation.

Lipophilicity value. Provides predictive information on drug permeability in cell/organ membranes and the compound's polarity being tested to determine its pharmacokinetic and pharmacodynamic profile. Lipophilicity as $\log P$ according to Lipinski rules of 5 (Ro5) with a value of $\log P<5{ }^{21}$. The results of the lipophilicity of the ${ }^{99 \mathrm{~m}} \mathrm{Tc}$ genistein kit had a log P value of $-0.77134 \pm 0.12$. These values indicate that this radiopharmaceutical kit is hydrophilic, can pass through the absorption mechanism well, with less active penetration into cells. Therefore, this log P result still complies with Lipinski's rule.

Electric charge. The charge of a compound can be determined by its separation and movement in an electric field. This charge can provide information on transport mechanisms in the body. Electrophoresis showed that the ${ }^{99 \mathrm{~m}} \mathrm{Tc}$ genistein kit did not migrate and remained at the starting point (scale 0). ${ }^{99 \mathrm{~m}} \mathrm{Tc}$ genistein kits are neutral, so there is no migration of the sample. In contrast, the ${ }^{99 m} \mathrm{Tc}$ movement from cathode to anode is due has a negative charge originating from $\mathrm{TcO}^{4-}$ (figure 2 ).

Plasma protein binding. The amount of ${ }^{99 \mathrm{~m}} \mathrm{Tc}$ genistein bound to plasma proteins was determined by the precipitation method. This method uses a 5\% TCA solution as a protein precipitation agent. The result of plasma protein binding of the ${ }^{99 \mathrm{~m}} \mathrm{Tc}$ genistein preparation was $75.29 \% \pm 2.59 \%$, indicating that this preparation was strongly bound to plasma proteins. 


\section{Conclusions}

The development of the synthesis of ${ }^{99 \mathrm{~m}} \mathrm{Tc}$ genistein kit was performed by direct labeling method, and simple quality control by TLC method by obtaining radiochemical purity that met the requirements. Determination of physicochemical properties showed that the ${ }^{99 \mathrm{~m}} \mathrm{Tc}$ genistein compound has good properties and is potentially developed into a radiotracer kit for breast cancer.

\section{References}

1. World Health Organization (WHO). Global Health Estimates 2020: Deaths by Cause, Age, Sex, by Country and by Region, 2000-2019. WHO; 2020. Accessed December 11, 2020. who.int/ data/gho/data/themes/mortality-andglobal-health-estimates/ghe-leadingcauses-of-death.

2. World Health Organization. Guide to Early Cancer Diagnosis. 2017.

3. Heather A. Parsons, Justin Rhoades, Sarah C. Reed, Gregory Gydush, Priyanka Ram, Pedro Exman, et al. Sensitive Detection of Minimal Residual Disease in Patients Treated for Early-Stage Breast Cancer. 2020. Clin Cancer Res; 26(11): 2556-64

4. Cheang MC, Chia SK, Voduc D, Gao D, Leung S, Snider J, et al. Ki67 index, HER2 status, and prognosis of patients with luminal B breast cancer. Journal of the National Cancer Institute. 2009; 101: 736-50.

5. Vallejos CS, Gomez HL, Cruz WR, Pinto JA, Dyer RR, Velarde R, et al. Breast Cancer Classification According to Immunohistochemistry Markers: Subtypes and Association With Clinicopathologic Variables in a Peruvian Hospital Database. Clinical breast cancer. 2010; 10: 294-300.

6. Maric P, Ozreti_c P, Levanat S, Oreskovi_c S, Antunac K, Beketi_c-Oreskovi_c L. Tumor markers in breast cancereevaluation of their clinical usefulness. Coll Antropol. 2011;35(1):241-247.

7. Perou, C. M., Sorlie, T., Eisen, M. B., van de Rijn, M., Jeffrey, S. S., Rees, C. A., et al. Molecular portraits of human breast tumours. Nature. 2000, 406: 747-752.

8. Ronis, M. J. Effects of soy containing diet and isoflavones on cytochrome P450 enzyme expression and activity. Drug Metab. Rev. 2016, 48: 331-341.

9. Hua Jiang, Jingjing Fan, Lin Cheng, Pan Hu, Renbin Liu., The anticancer activity of genistein is increased in estrogen receptor beta I-positive breast cancer cells. Onco Targets and Therapy. 2018, 11: 8153-63.

10. Ting, G.; Chang, C.-H.; Wang, H.-E. Cancer Nanotargeted Radiopharmaceuticals for Tumor Imaging and Therapy. Anticancer Res. 2009, 29: 4107-18.

11. Ilem-Ozdemir, D.; Asikoglu, M.; Ozkilic, H.; Yilmaz, F.; Hosgor-Limoncu, M.; Ayhan, S. Gamma Scintigraphy and Biodistribution of ${ }^{99 \mathrm{~m}} \mathrm{Tc}$-Cefotaxime Sodium in Preclinical Models of Bacterial Infection and Sterile Inflammation. J. Labelled Comp. Radiopharm. 2016, 59, 109-116.

12. Brooks, G. F.; Carroll, K. C.; Butel, J. S.; Morse, S. A.; Mietzner, T. Pathogenesis of Bacterial Infection. Jawetz, Melnick and Adelberg's Medical Microbiology; Appleton-Lange: Stanford, 1998; pp. 
134-144.

13. Rennen, H. J. J. M.; Boerman, O. C.; Oyen, W. J. G.; Corstens, F. H. M. Imaging Infection/Inflammation in the New Millennium. European Journal of Nuclear Medicine 2001, 28: 241-252.

14. Ramdhani D, Sriyani M.E., Ayu F, Technetium-99m-labeled genistein as a potential radical scavenging agent. Journal of Advanced Pharmaceutical Technology \& Research. 2019; 10: 112-6.

15. United States Pharmacopeial Convention. Official Monographs: USP 28. Technetium ${ }^{99 m}$ Tc-Pertechnetate Injection (Sodium). United States Pharmacopeia (USP) 28-National Formulary; 2005.

16. Owunwanne A, Patel M, Sadek S. The Handbook of Radiopharmaceuticals. London: Chapman and Hall Medical; 2012.

17. Khan, N.-U.-H.; Naqvi, S. A. R.; Sohail, H.; Roohi, S.; Jamal, M. A. Technetium-99m Labeled Ibuprofen: Development and Biological Evaluation Using Sterile Inflammation Induced Animal Models. Mol. Biol. Rep. 2019, 46, 3093.

18. Vladimir Sadkin, Viktor Skuridin, Evgeny Nesterov, Elena Stasyuk, Alexander Rogov, et. al, ${ }^{99 \mathrm{~m}} \mathrm{Tc}$ labeled nanocolloid drugs: development methods. Scientific Reports. 2020. 10:14013

19. Saha, G. B., Fundamentals of Nuclear Pharmacy. 5th Edition penyunt. New York: Springer-Verlag. 2010.

20. Zolle, I. Technetium-99m Pharmaceuticals: Preparation and Quality Control. New York: Springer Berlin Heidelberg New York. 2007.

21. Waring, M.J. Lipophilicity In Drug Discovery. Expert Opinion on Drug Discovery. 2010. 5(3): 235-248.

\section{Figures}

\section{Radiopharmaceutical kit}

\section{Targeting radiotracer}

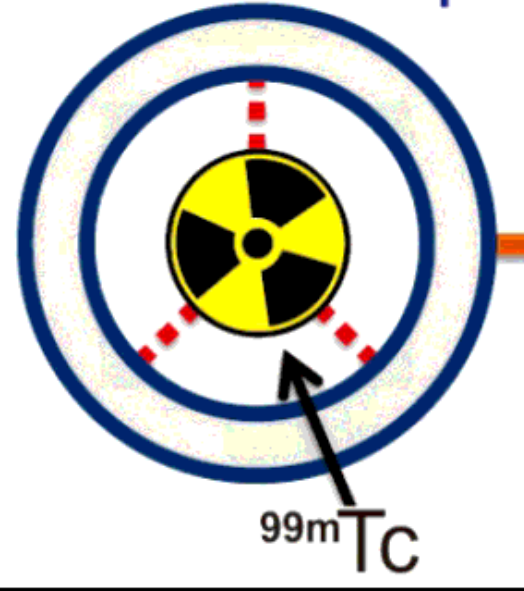

\section{Genestein}
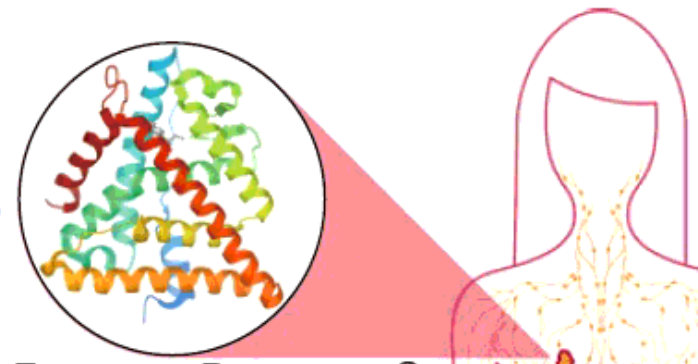

Estrogen Receptor- $\beta$



\section{Figure 1}

Figure 2. The general scheme of $99 \mathrm{mTc}$ genistein kit as a radiotracer for breast cancer. 


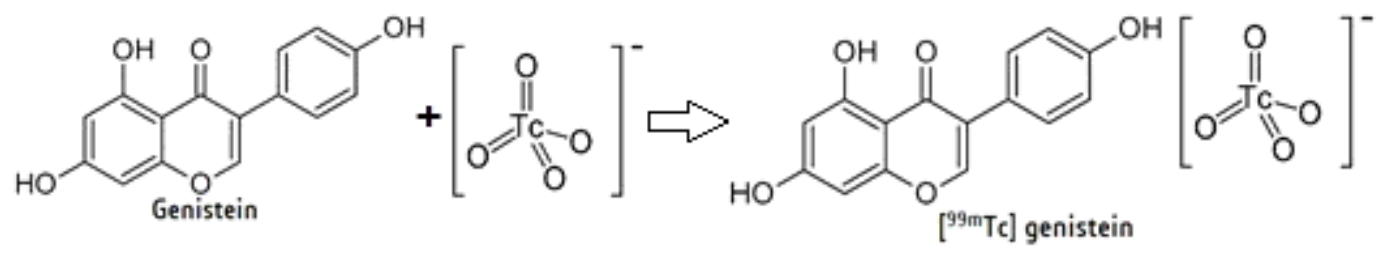

\section{Figure 2}

Figure 1. Schematic design of the direct radiolabeling method for $99 \mathrm{mTc}$ genistein.

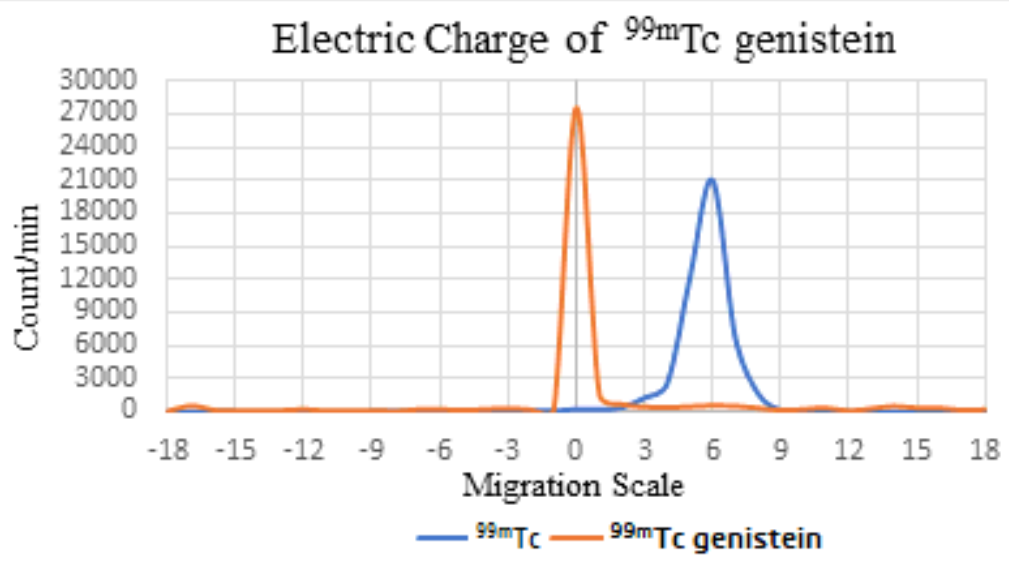

\section{Figure 3}

Figure 2. Electric charge $99 \mathrm{mTc}$ genistein kit with electrophoresis. 